\title{
Impacts of waste water from main factories on water quality of Tolich river, Hanoi
}

\author{
Nguyen Dinh Dap ${ }^{1, *}$ \\ ${ }^{1}$ Moscow State University of Civil Engineering, 129337, Yaroslavskoye Shosse 26, Moscow, Russia
}

\begin{abstract}
Waste water from industrial sites amount to one third of total waste water discharged into Tolich river and may have serious effects on the river water quality. With the total amount of waste water of factories (Hanoi beer alcohol and beverage joint stock corporation - HABECO, Trang An JSC and Thuong Dinh industrial park) of $45000 \mathrm{~m}^{3} /$ day, these factories account for more than a half of total industrial waste water released into Tolich river. The analytic results of waste water from the main factories (HABECO, Trang An JSC, Thuong Dinh industrial park, Hanoi Soap JSC, Sao Vang Rubber JSC, Tool No.1 JSC) show that the parameters of TSS, $\mathrm{BOD}_{5}, \mathrm{COD}$, total of nitrogen, total of phosphorus are higher than the Vietnamese standards for industrial waste water QCVN 24:2009/MONRE, column B, because the factory has an effective wastewater treatment system. The heavy metals parameters of waste water from all factories without treatment: HABECO releases 1974 tons of BOD, 766 tons of TSS, 8,4 tons of phosphorus and 52,5 tons of nitrogen annually; Trang An JSC releases 64,8 tons of BOD, 48,6 tons of TSS, 0,6 tons of phosphorus, 1,6 ton of nitrogen and 25 tons of oil and grease; HASO releases 30 tons of BOD, 33 tons of TSS and 5 tons of oil and grease. Thus, if the waste water is not treated, it can lead to a very seriously pollution of Tolich river.
\end{abstract}

\section{Problem statement}

Hanoi is the capital of Vietnam, total area of $3345 \mathrm{~km}^{2}$ with population of 7,7 million people in 2016. Average population density is 1979 people $/ \mathrm{km}^{2}$, however, in some inner districts, the figure reached up more than $35000 / \mathrm{km}^{2}$ [1]. Currently, population in inner Hanoi is 2,6 million people with annual growth rate of $3,8 \%$, of which in-minigration contributes roughly $3 \%$ [2].

The main sources of pollution in urban inner Hanoi include: domestic waste water from the source of residential areas and source of commercial service is estimated as 723000 $\mathrm{m}^{3} /$ day [3]. The total volume of waste water from industrial zones, industrial clusters in Hanoi is estimated around $80000 \mathrm{~m}^{3} /$ day. The volume waste water of hospitals discharged daily at approximately $6000 \mathrm{~m}^{3} /$ day [3].

There are four main rivers forming Tolich river system, which receives wastewaters from inner city of Hanoi and covers a basin area of $77,5 \mathrm{~km}^{2}$ [2]. Tolich is the biggest river

\footnotetext{
* Corresponding author: nguyendinhdap@gmail.com
} 
receiving wastewaters from western part of Hanoi, while Kim Nguu, Set and Lu are three smaller ones receiving wastewaters from eastern part before discharging to Tolich river in downstream. Tolich river originates from West Lake in North Hanoi, receiving mainly domestic waste water in upstream and mix of domestic and industrial waste water in downstream before joining Nhue river in South Hanoi through Thanh Liet Dam [2].

There have recently been many studies of status of water quality and solutions of Tolich river. However, there isn't much data surveys and impacts assessment of sources affecting to water quality of the river, especially industrial waste water. The sources account for more than one-third of total volume of waste water of Tolich river, but industrial waste water containing toxic compounds are cumulative of heavy metals or persistent organic biological compound, research of waste water will positively contribute to the understanding of pollution status and sources [4]. Since then, the proposed measures can help to manage the water quality of Tolich river.

\section{Materials and methods research}

\subsection{Study site}

There are five industrial zones located in Tolich river system basin, in which no suitable wastewater treatment systems are available [4]. Thuong Dinh industrial park consists of 30 manufacturing plants, which have been directly discharging un- and/or partially treated wastewater to downstream reach of Tolich river. Those plants include: fourteen of mechanical industry, four of textile industry, three of leather industry, two of chemical industry (rubber and soap), two of ceramic industry, one of tobacco industry, one of paper industry, and three others. Other four industrial zones, including 69 plants of all types of industries, discharge wastewater to Lu, Set, and Kim Nguu rivers, before entering Tolich river in downstream (Fig. 1).

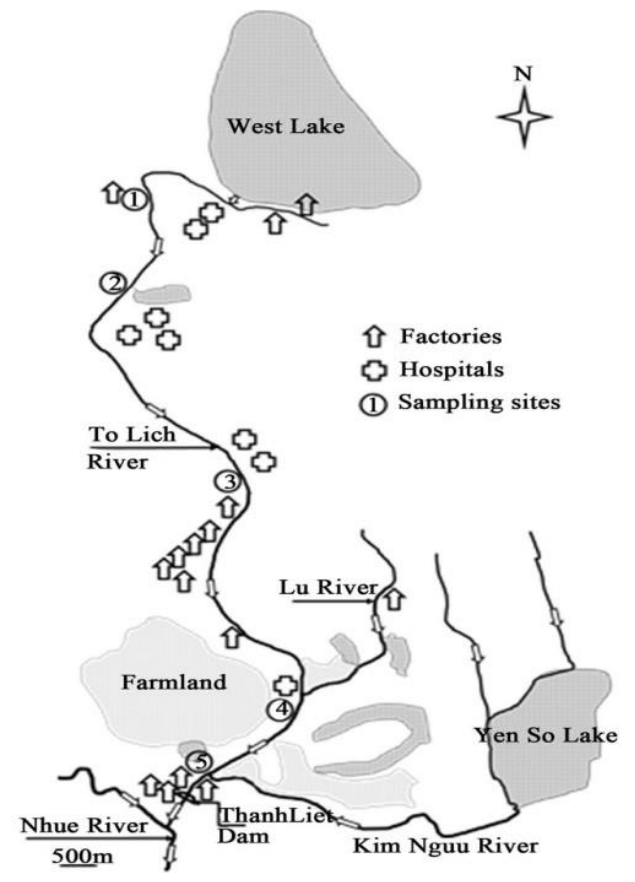

Fig. 1. Map of study area showing sampling sites. 
Tolich river system is under high polluted condition as result of diversity of wastewaters discharged from various sources such as industry, hospitals, households, agriculture... There are about 2 million permanent citizens living in inner city Hanoi and seasonal citizens, generating domestic wastewater to Tolich river system an estimated volume of more than $190000 \mathrm{~m}^{3} /$ day. Meanwhile, discharge from industries ranges between 240000 to $263000 \mathrm{~m}^{3} /$ day, occupying $53-58 \%$ of the total waste water from inner city [5]. There are five industrial zones located in Hanoi including 99 large manufacturing plants of all types of industries, which release wastewater to Tolich river system. In addition with 369 large and medium scale industries, there are 14000 small industries and handicrafts located in Hanoi, 29 hospitals and many big health centers also discharge roughly $6000 \mathrm{~m}^{3}$ wastewater per day to Tolich river system (Table 1) [5].

Table. 1. List of manufacturing plants of five industrial zones in basin of Tolich river system.

\begin{tabular}{|l|c|c|c|c|c|}
\hline \multicolumn{1}{|c|}{ Type of industry } & $\begin{array}{c}\text { Thuong Dinh- } \\
\text { Nguyen Trai }\end{array}$ & $\begin{array}{c}\text { Minh Khai- } \\
\text { Vinh Tuy }\end{array}$ & $\begin{array}{c}\text { Thuong Dinh- } \\
\text { Duoi Ca }\end{array}$ & $\begin{array}{c}\text { Van Dien- } \\
\text { Phap Van }\end{array}$ & $\begin{array}{c}\text { Cau } \\
\text { Buou }\end{array}$ \\
\hline Mechanical & 14 & 13 & 3 & 8 & 3 \\
\hline $\begin{array}{l}\text { Construction } \\
\text { material }\end{array}$ & - & 6 & - & 2 & 1 \\
\hline Food processing & 1 & 3 & 6 & - & - \\
\hline Textile & 4 & 11 & 2 & - & - \\
\hline Leather & 3 & 1 & - & - & - \\
\hline Printing & - & 1 & - & - & - \\
\hline Paper & 1 & - & - & - & - \\
\hline Ceramic & 2 & - & 1 & - & - \\
\hline Chemical & 2 & - & - & 2 & 1 \\
\hline Others & 3 & 3 & 1 & 1 & - \\
\hline Total & 30 & 38 & 13 & 13 & 5 \\
\hline
\end{tabular}

\subsection{Study method}

Using statistical method, compare: String data is used to calculate the results observed for many years, on the basis of applicable regulations allowed for each type of waste water compared with the permitted Regulation that assess water quality.

Regulations applicable to evaluate the quality of wastewater: Value column B of Regulations industrial wastewater QCVN28:2010/MONRE (Ministry of Nature Resources and Environment Vietnam); Regulation applied to evaluate the quality of industrial wastewater: Value column B of Regulation industrial wastewater QCVN40:2011/MONRE; Regulations applied to assess water quality: Value column B2 of surface water quality standards QCVN08:2008/MONRE

To study the influence of waste water from some main factories on water quality fo Tolich river, in this research findings previous studies of river water quality were collected and synthesized. Then field surveying, site selecting and sampling the river's water and industrial waste water from some main factories to analyze and compare. The water samples were preserved and analyzed in the Laboratory of Environmental Analysis, Faculty of Environmental Sciences, Hanoi University of Sciences (Vietnam National University) in accordance with the Vietnamese standard methods. Analytic apparatus, including machine atomic absorption Spectrometry (AAS 6800, Japan), UV-VIS Spectrometer, and a number of common laboratory instruments and equipment are used. Samples of waste water from some main factories are presented on Table 2. 
Table 2. Samples of waste water from some main factories release into Tolich river.

\begin{tabular}{|c|c|c|}
\hline $\begin{array}{c}\text { Mark } \\
\text { sample }\end{array}$ & Name of factory & Explanation \\
\hline W1 & HABECO & Hanoi Beer Company \\
\hline W2 & Trang An JSC & Hanoi Cake - Candy - Jam Enterprise \\
\hline W3 & Thuong Dinh Industrial park & $\begin{array}{c}\text { General discharge of waste water in Thuong } \\
\text { Dinh Industrial park }\end{array}$ \\
\hline W4 & HASO & Hanoi Soap Joint Stock Company \\
\hline W5 & SRC & Sao Vang Rubber Joint Stock Company \\
\hline W6 & TJC & Tools Joint Stock company No 1 \\
\hline
\end{tabular}

The estimate of the deposition of pollutants in the water is carried out through computer modelling and the prediction of the distribution of pollutants in the river Tolich, taking into account the effect of sewage discharge. Methods of mathematical statistics and software packages for personal computers were used as general research methods (MS excel, Matlab, Waste)

\section{Results and discussion}

\subsection{Current status of water quality in Tolich river}

According to the analytic results of river water samples, Tolich river is generally very polluted especially in dry season. In rainy season, although water pollutants have been diluted, but it still does not ensure environmental hygiene. In particular, DO value increases from upstream to downstream river; $\mathrm{BOD}_{5}$ value at the Hoang Quoc Viet street and Cau Moi (Nga Tu So) are the lowest in the rainy season, respectively about 35 and $33 \mathrm{mg} / \mathrm{l}$, while that in Thuy Khue in the dry season is the highest $(68 \mathrm{mg} / \mathrm{l})$, COD is $65-91 \mathrm{mg} / 1$ (dry season) and about 50-74 mg/l (rainy season). Ratio between BOD/COD decreased gradually from upstream $(0,78 \mathrm{mg} / \mathrm{l})$ to the downstream side $(0,65 \mathrm{mg} / \mathrm{l})$.

TSS in river water is rather high from 69 to $135 \mathrm{mg} / \mathrm{l}$. Ammonium concentration in the river is very high (approximately the lowest is 2 times and the highest is 8,3 times higher than with QCVN08:2008, column B2). Nitrite concentration varies between 0,120 to 0,863 $\mathrm{mg} / \mathrm{l}$, higher than QCVN08:2008, column B2 (0,05 mg/l). Coliform beyond permissible limits in all samples (from 7 to 25 times) varies from $6,9.10^{4}$ to $2,5.10^{5} \mathrm{MPN} / 100 \mathrm{ml}$.

$\mathrm{pH}$ value and concentrations of $\mathrm{Fe}$ and heavy metals $(\mathrm{Zn}, \mathrm{Cd}, \mathrm{Cr}, \mathrm{Cu}, \mathrm{Mn})$ in all positions lie within the limit permitted under QCVN08:2008, column B2. However, Pb levels exceed permissible limits in some parts of the river, which flows through the Thuong Dinh industrial zone and river sites are influenced by discharge of industrial activity $(0,1295 \mathrm{mg} / \mathrm{l}$ at $\mathrm{Nga} \mathrm{Tu}$ So). These results are relatively consistent with other studies' findings.

\subsection{The composition of waste water from factories into Tolich river}

To assess the impact of waste water from chosen factories on Tolich river water quality, sampling and components analysis in waste water from some main factories are conducted (Table 3). 
Table 3. Composition analytic results of waste water from some main factories.

\begin{tabular}{|c|c|c|c|c|c|c|c|c|}
\hline \multirow[b]{2}{*}{ Parameters } & \multirow[b]{2}{*}{ Unit } & \multicolumn{6}{|c|}{ Samples of waste water from factories } & \multirow{2}{*}{$\begin{array}{c}\text { Standard } \\
\text { QCVN } \\
24: 2009 \text {, } \\
\text { column B }\end{array}$} \\
\hline & & W1 & W2 & W3 & W4 & W5 & W6 & \\
\hline Temperature & ${ }^{0} \mathrm{C}$ & 29,2 & 29,4 & 28,1 & 28,9 & 28,7 & 29,1 & 40 \\
\hline $\mathrm{pH}$ & - & 8 & 7,9 & 6,4 & 8,5 & 8,1 & 6,8 & $5,5-9$ \\
\hline TSS & $\mathrm{mg} / \mathrm{l}$ & 200 & 85 & 160 & 185,3 & 81 & 115 & 100 \\
\hline N-total & $\mathrm{mg} / \mathrm{l}$ & 35 & 25 & 25 & 26 & 23 & 22 & 30 \\
\hline P-total & $\mathrm{mg} / \mathrm{l}$ & 5,1 & 5,3 & 5,8 & 5,7 & 5,4 & 5,9 & 6 \\
\hline $\begin{array}{l}\text { BOD5 } \\
\text { (at } 20^{\circ} \mathrm{C} \text { ) }\end{array}$ & $\mathrm{mg} / \mathrm{l}$ & 250 & 45 & 70 & 69 & 81 & 60 & 50 \\
\hline COD & $\mathrm{mg} / \mathrm{l}$ & 350 & 75 & 108 & 104 & 79 & 106 & 100 \\
\hline $\mathrm{Fe}$ & $\mathrm{mg} / \mathrm{l}$ & 0,5689 & 0,5102 & 0,6421 & 0,6576 & 2,1512 & 1,8715 & 5 \\
\hline $\mathrm{Cr}^{3+}$ & $\mathrm{mg} / \mathrm{l}$ & 0,0125 & 0,0312 & 0,0625 & 0,0571 & 0,0781 & 0,0421 & 1 \\
\hline $\mathrm{Cu}$ & $\mathrm{mg} / \mathrm{l}$ & 0,0116 & 0,0183 & 0,0541 & 0,0149 & 0,0176 & 0,0132 & 2 \\
\hline $\mathrm{Cd}$ & $\mathrm{mg} / \mathrm{l}$ & 0,0013 & 0,0017 & 0,0054 & 0,0065 & 0,0057 & 0,0036 & 0,01 \\
\hline $\mathrm{Zn}$ & $\mathrm{mg} / \mathrm{l}$ & 0,0172 & 0,0234 & 0,0417 & 0,0167 & 0,0453 & 0,0716 & 3 \\
\hline $\mathrm{Pb}$ & $\mathrm{mg} / \mathrm{l}$ & 0,4110 & 0,2391 & 0,4961 & 0,4902 & 0,5012 & 0,4892 & 0,5 \\
\hline $\mathrm{Mn}$ & $\mathrm{mg} / \mathrm{l}$ & 0,0438 & 0,0517 & 0,1319 & 0,1376 & 0,1392 & 0,1903 & 1 \\
\hline
\end{tabular}

TSS, $\mathrm{BOD}_{5}$, COD of almost all factories exceed the legal standards. TSS in waste water of HABECO is the highest $(200 \mathrm{mg} / \mathrm{l})$, exceeding the correspondent standard QCVN24:2009, column B by 2 times. TSS in the waste water of Trang An JSC and SRC are the lowest - 85 and $81 \mathrm{mg} / \mathrm{l}$, respectively; $\mathrm{BOD}_{5}$ in waste water of all factories from 45 to $250 \mathrm{mg} / \mathrm{l}$, and almost exceed the QCVN24:2009, column B, except at Trang An JSC; COD in waste water from factories is quite high, three factories exceed QCVN24:2009, column B, except Trang An JSC and SRC.

Total nitrogen in waste water of HABECO exceeds the permitted limit, while other factories meet standard. Only parameters in Trang An JSC are standard. Because the factory has built a relatively efficient sewage treatment system.

The concentrations of total phosphorus in waste water from factories increase from upstream to downstream of the river (ranging from 5,1 to $5,9 \mathrm{mg} / \mathrm{l}$ ). In particular, total phosphorus concentration in Thuong Dinh industrial park is the highest.

So, factories impact the water quality in Tolich river. From the factory waste water analysis it is found that, the main pollutant in waste water (HABECO, Trang An JSC) are organic matter, nitrogen, TSS. The concentrations of non-biodegradable compounds, phosphorus, iron and other heavy metals in waste water of the factories in downstream of Tolich river (Thuong Dinh industrial park) are higher.

\subsection{The influence of pollutants load in factory waste water on water quality of Tolich river}

The process of sewage distribution along the length of the water streams in the form of a general scheme with three distinct zones with different degrees of mixing (Fig. 2) [6].

The initial data of the program are calculated, which uses the equation of material balance, include the following data: length $\mathrm{L}(\mathrm{m})$, average width $\mathrm{B}(\mathrm{m})$, average depth $\mathrm{H}$ $(\mathrm{m})$ in the study area and the average flow rate $(\mathrm{m} / \mathrm{s})$. 
y

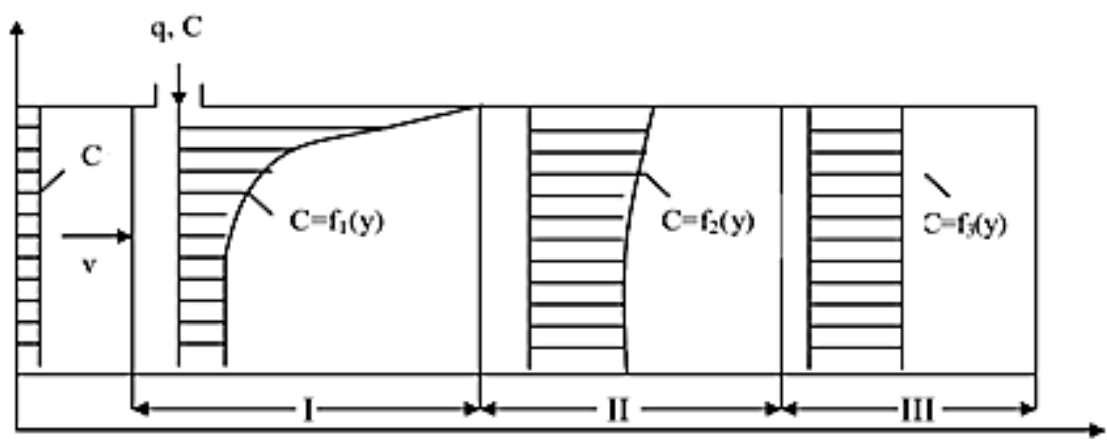

Fig. 2. Schematic diagram of wastewater distribution in watercourse.

Determination of concentrations of pollutants in the river under the influence of wastewater discharge by formulas [6]:

$$
\begin{aligned}
& u \frac{\partial u}{\partial x}+v \frac{\partial u}{\partial y}+w \frac{\partial u}{\partial z}=-\frac{1}{\rho} \frac{\partial \rho}{\partial x}+v_{1} \frac{\partial^{2} u}{\partial x^{2}}+v_{2} \frac{\partial^{2} u}{\partial y^{2}}+v_{3} \frac{\partial^{2} u}{\partial z^{2}}+f_{1} \\
& u \frac{\partial v}{\partial x}+v \frac{\partial v}{\partial y}+w \frac{\partial v}{\partial z}=\frac{1}{\rho} \frac{\partial \rho}{\partial y}+v_{1} \frac{\partial^{2} v}{\partial x^{2}}+v_{2} \frac{\partial^{2} v}{\partial y^{2}}+v_{3} \frac{\partial^{2} v}{\partial z^{2}}+f_{2} \\
& u \frac{\partial w}{\partial x}+v \frac{\partial w}{\partial y}+w \frac{\partial w}{\partial z}=-\frac{1}{\rho} \frac{\partial \rho}{\partial z}+v_{1} \frac{\partial^{2} w}{\partial x^{2}}+v_{2} \frac{\partial^{2} w}{\partial y^{2}}+v_{3} \frac{\partial^{2} w}{\partial z^{2}}+f_{3} \\
& \frac{\partial u}{\partial t}+\frac{\partial v}{\partial y}+\frac{\partial w}{\partial z}=0 \\
& \frac{\partial C}{\partial t}+u \frac{\partial C}{\partial x}+v \frac{\partial C}{\partial y}+w \frac{\partial C}{\partial z}=\frac{\partial}{\partial x}\left(D_{x} \frac{\partial C}{\partial x}\right)+\frac{\partial}{\partial y}\left(D_{y} \frac{\partial C}{\partial y}\right)+\frac{\partial}{\partial z}\left(D_{z} \frac{\partial C}{\partial z}\right)-\lambda_{C}+W
\end{aligned}
$$

where $\quad u(x, y, z) ; v(x, y, z) ; w(x, y, z)$ - components of the velocity field

$C(t, x, y, z)$ - admixture concentration

$\rho$ - liquid density

$f_{i}$ - components of force vector

$W$ - source of pollution.

$D_{x}, D_{y}, D_{z}$ - Parameters diffusion coefficients assumed to simplify the solution of the problem

Total waste water of the surveyed factories (HABECO, Trang An JSC, Thuong Dinh industrial park), is about $45000 \mathrm{~m}^{3} /$ day, accounting for more than a half of total industrial waste water discharged into the river. Although, the waste water flow from factories is not high in compare with the main sources of the river. Because it includes many nonbiodegradable pollutants, it can cause severe and lasting pollution for the Tolich river.

Result show that, with current capacity the annual pollutants loads in factory waste water are as follows: HABECO discharges about 1974 tons of BOD, 766 tons of TSS, 8,4 tons of phosphurus and 52,5 tons of nitrogen; Trang An JSC - 64,8 tons of BOD, 48,6 tons tons of TSS, 0,6 tons of total phosphorus, 1,6 tons of nitrogen and 25 tons of oil and grease; HASO - 30 tons of BOD, 33 tons of TSS and 5 tons of oil grease.

Thus, the pollutants loads in waste water by three surveyed factories are quite high and 
the highest is at HABECO. If this waste water is not treated before being discharged into the river, it will greatly affect the water quality of Tolich river. Through the results of monitoring water quality in Tolich river there are some remarks as following: Dissolved oxygen concentration (DO) in the surface water of the river sis low, below the laval of development of some species $(>4)$. During the dry season the measured value $i_{\text {i }}$ range from 0,1 to $7 \mathrm{mg} / \mathrm{l}$. There are $33 \%$ of the monitoring values of DO lower than NTR $(<2 \mathrm{mg} / \mathrm{l}) . \mathrm{BOD}_{5}$ contents beyond the allowable limit of NTR from 1,1 to 20 times (there are $33 \%$ of the monitoring values exceeded NTR). COD values at all monitoring sites exceed NTR from 1,1 to 10 times (there are $97 \%$ of the monitoring values exceed NTR). The result showed that the level of organic pollution in the river is high (Fig. 3 and Fig. 4).

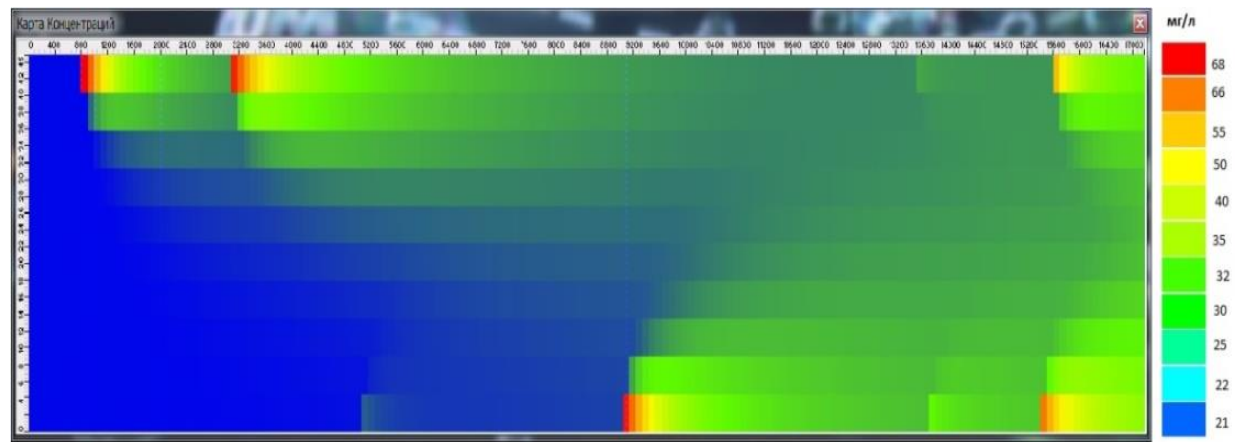

Fig. 3. Map of $\mathrm{BOD}_{5}$ concentrations in the Tolich river under the influence of wastewater discharge.

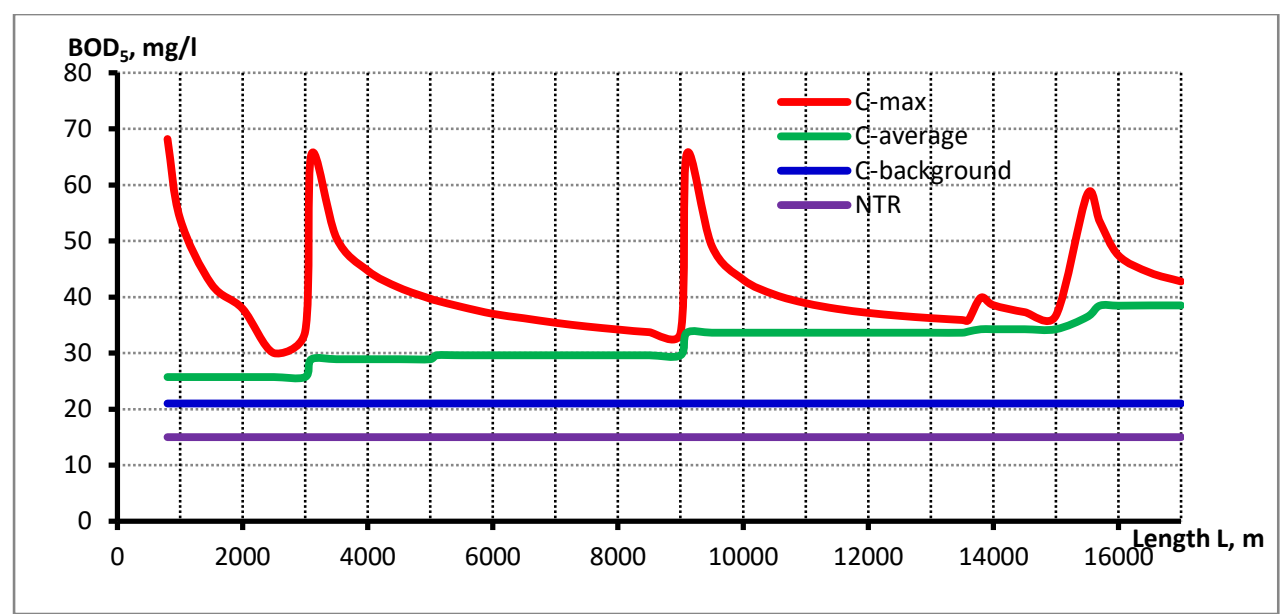

Fig. 4. Graphic arts of changes maximum and average concentrations $\mathrm{BOD}_{5}$ in Tolich river.

Nutrients: $\mathrm{NH}_{4}{ }^{+}$contents of ammonium at all posstitions are higher than NTR exceed the limit of NTR from 9,75 to 58,5 times. $\mathrm{PO}_{4}{ }^{3--}$ : phosphate contents at all monitoring sites exceed NTR from 1,2 to 52 times.

Oil total: total oil contents at monitoring sites are rather high, ranging 0,1 to $18,8 \mathrm{mg} / \mathrm{l}$. Propotion of samples exceeding NTR accounts for $97 \%$, from 1,3 to 66 times.

Coliform: total coliform contents are at high levels, ranging from 2300 to $11.10^{7}$ MPN/100 ml.

Heavy metals: there are heavy metal pollution in the river as for $\mathrm{Fe}$, there are $23 \%$ values exceeding NTR, from 1,1 to 20 times higher NTR, and $\mathrm{Cr}^{6+}(10,8 \%$ values exceeding NTR, from 1,3 to 4 times higher than NTR). 


\section{Conclusions and recommendations}

In most of the entire of Tolich river the parameters of DO, COD, $\mathrm{BOD}_{5}, \mathrm{TSS}, \mathrm{NH}_{4}{ }^{+}, \mathrm{NO}_{2}{ }^{-}$, coliform are higher than standards. However, the levels of Fe and heavy metals such as $\mathrm{Zn}$, $\mathrm{Cd}, \mathrm{Cr}, \mathrm{Cu}, \mathrm{Mn}$ meet the standard, only the concentration of $\mathrm{Pb}$ exceeds the permitted standards, especially in Thuong Dinh industrial park. The quality of discharge water from factories into rivers: the parameters such as $\mathrm{TSS}, \mathrm{BOD}_{5}, \mathrm{COD}$, nitrogen, phosphorus in waste water discharging into the Tolich river from the factories (HABECO, Thuong Dinh industrial zone, HASO, SRC, TJC) do not meet the permitted standards. Only Trang An JSC has installed a water treatment system, so its waste water discharge meets the standard. The concentrations of heavy metal in waste water of the factories meet the standard. Calculations of pollutants loads in waste water from some factories by IPC software show that, if not treated, the annual pollutants loads of HABECO are about 1974 tons of BOD, 766 tons of TSS, 8,4 tons of phosphorus and 52,5 tons of nitrogen; Trang An JSC approximately 64,8 tons of BOD, 48,6 tons of TSS, 0,6 tons of phosphorus, 1,6 tons of nitrogen, 25 tons of oil and grease; HASO about 30 tons of BOD, 33 tons of TSS, 5 tons of oil and and grease. So, if not treated before being discharged into Tolich river, cause serious pollution to the river. In order to improve water quality management, it's necessary to strengthen the monitoring system of water environment with an increase of monitoring points, monitoring frequency and parameters; and a better quality assurance and quality control. In addition, the database should be easily access for publicity, which benefits not only local government but also citizens. These monitoring and information solutions may contribute to a more effective management of quality of Tolich river and all water bodies in Hanoi city in general. Hanoi Department of Natural Resourches and Environment will conduct the checking, monitoring and sanctioning the organization which cause pollution.

Due to land in the urban area cramped irrelevant for the rehabilitation of sewer separately. Thus the construction of the collection system and wastewater treatment in residential areas with 10000 people/collection and treatment system and then transferred to the treatment plant is neccessary. Besides, the apartment buildings, new urban areas should have wastewater collection system and wastewater treatment system before disharge to the combined sewer system of the city.

Inner Hanoi shares the sewerage system with the drainage system, as this is one of the difficult and expensive for the wastewater treatment. Major sources of urban areas including domestic waste, hospital waste resources and industrial discharges. In the future, the city has planned a number of sewage treatment plants, however, focuses on the one hand to solve the situation, but in the long time we need long-term solutions for the effective and sustainable development. The above solution given to wastewater treatment in resource efficient will contribute to improve and control the quality of waste water from the source of pollution is effective in terms of economic and sustainable development to human health and the environment for Hanoi city.

\section{References}

1. V. Voshanik, N. Dzhumagulova, et.al. Ecology of Urban Areas 1, 39-44 (2017)

2. N. Dinh Dap, V. Voshanik, et.al. Water supply and sanitary technique 12, 20-25 (2017)

3. N. Dinh Dap, V. Voshanik, et.al. Safety in Technosphere 5(68), 9-15 (2017)

4. N. Dinh Dap, V. Voshanik, N. Dzhumagulova, Vesnik KRSU 12, 112-117 (2017)

5. N. Dinh Dap, V. Voshanik, M. Slesarev, et.al. Ecology of Urban Areas 1, 35-40 (2018)

6. I.D. Rodziller, Prediction water quality of reservoirs-receivers of sewage (Moscow, EDP Strouzdat, 1984) 